\title{
Chapter 10 \\ Fostering Critical Thinking as a Life Skill to Prevent Child Marriage in Honduras: The Case of Holistic Education for Youth (HEY!)
}

\author{
Diana Pacheco-Montoya and Erin Murphy-Graham
}

\begin{abstract}
This chapter presents findings from a design-based research project between the University of California, Berkeley and a Honduran non-governmental organization, Bayan Association called Holistic Education for Youth (HEY!). We explain why critical thinking is a crucial life skill to prevent child marriage in rural areas of Honduras and illustrate how critical thinking (specifically around gender inequality and marriage) was incorporated into a secondary school curriculum. We describe the pedagogies used to develop this curriculum and offer insights about its implementation. Finally, using classrooms observation and interview data, we discuss how students developed critical thinking and decision-making skills related to the gender inequality in society that has perpetuated the practice of child marriage.
\end{abstract}

Keywords Child marriage $\cdot$ Gender equality $\cdot$ Critical thinking $\cdot$ Secondary education $\cdot$ Honduras $\cdot$ Design-based research

\section{Acronyms}

HEY! Holistic Education for Youth

DHS Demographic Health Surveys

DBR Design-based research

SAT Sistema de Aprendizaje Tutorial (Tutorial Learning System)

SRH Sexual and reproductive health 


\section{Introduction}

More than one-third of girls in developing countries are married before the age of 18 and one in nine are married before their fifteenth birthday. If current trends continue, 150 million girls will marry before the age of 18 over the next decade (ICRW, 2015). Preventing early, child, and forced marriage is a major goal of the international community, evidenced by target 5.3 of the Sustainable Development Goals. ${ }^{1}$ Child marriage is a global problem, as it is found in every region of the world, but it has different characteristics that are contextually-specific (Girls Not Brides, 2020). Education has been identified as an important strategy to delay marriage; trends from Demographic Health Surveys (DHS) indicate that as girls' participation in secondary education increases, rates of child marriage decrease (Bongaarts et al., 2017).

Latin America, however, has not experienced a significant reduction in child marriage as education levels have increased, making it a global outlier in this regard. An analysis of trends in education and reproductive outcomes in DHS data from 43 countries (since 1986) found that in all world regions other than Latin America, with increases in educational attainment, age of first sexual intercourse, first marriage, and first birth increased correspondingly (Bongaarts et al., 2017). But in Latin America, the age of first sexual intercourse decreased by almost a year, age at marriage increased by less than a year, and the age at first birth remained constant despite increased levels of education. As a result, although Latin America does not have the highest rate of child marriage globally, it is the only region in the world where it is not decreasing. If these trends continue and no tangible efforts and investments take place for prevention, the region is projected to have the second highest child marriage rate in the world by 2030 (UN Women et al., 2018). This troubling scenario raises urgent questions about the connections between the quality of education and the prevention of child marriage in Latin America. Often what students study in secondary school is disconnected from their context and does not cultivate the life skills that they need to "do life well" (Murphy-Graham and Cohen, Chap. 2, this volume). Particularly, schooling may not foster critical thinking - a key life skills domain valued across different life skills frameworks and discourse communities (Murphy-Graham and Cohen, Chap. 2, this volume).

In this chapter we turn to the question of how a curriculum can foster critical thinking among youth, particularly in the context of their thinking and decisionmaking regarding gender inequality and marriage. We present findings from a design-based research project that builds upon a 20-year research-practice partnership between the University of California, Berkeley and a Honduran nongovernmental organization, Bayan Association. Our collaboration began with a shared goal of examining the underlying causes of child marriage in Honduras, and

\footnotetext{
${ }^{1}$ Child Marriage is defined as "a marriage of a girl or boy before the age of 18 and refers to both formal marriages and informal unions in which children under the age of 18 live with a partner as if married" (UNICEF, 2017, p.1).
} 
resulted in the design of an educational intervention, a program called Holistic Education for Youth (HEY!). The aim of HEY! is to prevent child marriage through an interactive curriculum that supplements the existing curriculum for grades 7-11 and that focuses on fostering the life skills of critical thinking and decision-making so that youth can make informed choices about their futures. Here, we share findings from our study that explain why critical thinking is a key life skill to prevent child marriage in rural areas of Honduras. We illustrate how additional materials emphasizing critical thinking (specifically around gender inequality and child marriage) were incorporated into a secondary school curriculum and highlight the pedagogies that can support critical thinking and decision-making. We then examine how critical thinking can foster cognitive processes that inform adolescents' decision-making.

\section{Research Context and Background}

Almost half (48.3\%) of the population of Honduras lives in poverty, and high levels of crime and violence have stymied economic growth (World Bank, 2020). Honduras has one of the highest rates of child marriage in the Western Hemisphere, with the fourth highest prevalence of child marriage (34\%) in Latin America after Brazil (36\%), Dominican Republic (41\%), and Nicaragua (41\%) (UNICEF, 2016). Poor, rural Honduran girls are the most vulnerable to child marriage, and approximately $8 \%$ of girls are married by the age of 15 (Honduran Secretary of Health et al., 2013). While child marriage is technically illegal, the vast majority of unions are informal: in Honduras, only $10 \%$ of unions formed by adolescents are legal (Remez et al., 2009). Therefore, legislation alone is insufficient to reduce child marriage. Despite the lack of ritualization and legalization, consensual unions are socially perceived as formal marriages. That is, once a couple lives together, they are considered husband and wife (Murphy-Graham \& Leal, 2015).

Murphy-Graham and Leal (2015) found that, in rural areas of Honduras, girls exercised agency in their decisions to marry. Girls' agency, or their "socioculturally mediated capacity to act" (Ahearn, 2001, p. 112) was characterized as simultaneously "thin, opportunistic, accommodating, and oppositional" (p. 25). Their agency was "thin" because they were driven to marriage by the limitations of their context, and "opportunistic" because young girls saw marriage as an opportunity to gain freedom and/or improve their financial well-being. Girls in the study reported experiencing limitations on their mobility and ability to socialize with their peers given the control their parents or grandparents exerted over them due to fear that girls would engage in romantic relationships or run away with their partners. The agency exercised by these girls was also described as "accommodating" since girls adapted to the traditional gender roles that were prevalent in their communities. Given the few alternative options for girls besides being wives and mothers, girls adjusted to these roles and saw them as worthwhile. Finally, their agency was "oppositional" because girls married against their parents' or other adults' advice. Murphy-Graham 
and Leal's (2015) results suggest that girls are not forced or coerced into to marry by their parents, community members, or their partners. Rather, in most cases, girls chose to begin cohabitating with their partners (often running away from home after a hasty decision). Their research and other studies suggest that girls' decision to marry is influenced by poverty, the lack of alternative life options available other than becoming a mother and housewife, and social norms around early marriage (Murphy-Graham \& Leal, 2015; Taylor et al., 2015, 2019; UNICEF, 2017). The implications of this research informed the design of HEY!, as we identified a need to work with girls (and boys) to improve their critical thinking and decision-making skills and to challenge the social norms that contributed to child marriage. Secondary schools are an ideal site to work with youth on critical thinking and decisionmaking, as the Honduran government is currently attempting to universalize schooling through grade 9.

\section{Secondary Education in Honduras}

For the past two decades the Honduran government, with multilateral and bilateral partners, has attempted to expand secondary education coverage. There is still a great deal of progress to be made: UNICEF data indicates just under half of adolescents are enrolled in lower secondary school and approximately $30 \%$ of adolescents are enrolled in upper secondary school (UNICEF, 2019) - signalling the serious challenge Honduras faces to achieve universal participation in lower and upper secondary school. Recently the government has attempted to promote alternative modalities for secondary school completion, particularly in rural areas. One such model, Sistema de Aprendizaje Tutorial (Tutorial Learning System, or SAT), is implemented as a partnership between the Honduran government and Bayan Association. SAT is an alternative secondary education program for rural areas of Honduras whose populations are not served by the traditional public-school system. Although SAT is administered by Bayan, SAT is fully funded by the Honduran government and SAT students receive the same academic credentials as those from traditional schools (i.e. they receive the same high school diploma). SAT has its own curriculum but complies with the core subjects as established by the national curriculum. SAT encompasses lower (7th-9th grades) and upper (10th-12th grades) secondary education levels.

SAT is a rare example of a cost-effective system of teaching and learning, particularly for rural areas. Results from a quasi-experimental impact evaluation found that students in SAT had $45 \%$ higher rates of learning than their counterparts in traditional rural secondary schools in Honduras (McEwan et al., 2015). SAT has operated in rural areas of Colombia, Honduras, Nicaragua, and Ecuador for over three decades, serving youth in remote rural areas, in a public-private partnership between the government and local NGOs. Despite these positive characteristics, our previous research and interviews in SAT communities revealed high rates of child marriage (see Murphy-Graham et al., 2020; Murphy-Graham \& Leal, 2015). Our 
research team, together with staff from Bayan, were in agreement that SAT could do more to confront this social problem. We worked together to launch HEY! in January 2016.

While we recognized the opportunity to create a school-based intervention with Bayan that addressed the causes of child marriage, we also were aware that there are structural causes of child marriage, such as poverty, state fragility, and lack of economic and educational opportunities, that are beyond the scope of what schools can be expected to change. What was feasible for our research-practice partnership was to enhance the SAT curriculum with materials that more explicitly examine social norms, family relationships, knowledge about child marriage, and decision-making processes. With these ideas in mind, we created HEY! with the goal of helping students think critically and make informed decisions about marriage in a setting where they have a constrained choice set, given the sociopolitical and economic context.

\section{Methodology}

Design-based research (DBR) is a fairly new methodology "designed with and for educators that seeks to increase the impact, transfer, and translation of education research into improved practice" (Anderson \& Shattuck, 2012, p.16). DBR attempts to close the gap between the problems and issues of everyday practice and research by designing and developing interventions that aim to create solutions to complex educational problems, thereby generating usable knowledge (Design Based Research Collective, 2003). As such, its purpose is not limited to creating programs or interventions; DBR advances knowledge about the characteristics of design strategies and processes, with the intention of developing interventions and generating and/or validating theory (Plomp, 2010). There are six stages in a DBR intervention (Mintrop, 2016). Table 10.1 describes each stage, how it was addressed in HEY!, and the dates of each stage:

From March to June 2016, we conducted the first three stages of this DBR study. ${ }^{2}$ In order to understand the problem and generate ideas for changing child marriage practices, we conducted a needs assessment of the SAT schools and communities were HEY! would be tested. This assessment included focus groups with teachers $(\mathrm{N}=1)$, SAT coordinators $(\mathrm{N}=1)$, and students, parents, and community leaders $(\mathrm{N}=3)$. We also interviewed stakeholders (activists and government representatives) $(\mathrm{N}=5)$ and former SAT students $(\mathrm{N}=2)$. We hosted and developed a design workshop, where key stakeholders - including staff at Bayan, teachers, parents, Secretary of Education representatives, and students - came together for a three-day interactive session where we jointly agreed on the conditions that cause child marriage and the potential ways that we could address those problems in SAT. This

\footnotetext{
${ }^{2}$ This study was approved by the ethics review board of the University of California, Berkeley, and it followed ethical guidelines for research with young people in Honduras.
} 
Table 10.1 Stages of a DBR study, how they were addressed in HEY!

\begin{tabular}{|c|c|c|}
\hline Stage & Description & Date \\
\hline $\begin{array}{l}\text { 1. Defining and } \\
\text { framing problem of } \\
\text { practice }\end{array}$ & $\begin{array}{l}\text { Researchers and educational leaders defined and framed } \\
\text { child marriage as a problem of practice because educational } \\
\text { expansion did not lead to child marriage reduction. }\end{array}$ & \multirow[t]{3}{*}{$\begin{array}{l}\text { March- } \\
\text { June } 2016\end{array}$} \\
\hline $\begin{array}{l}\text { 2. Making intuitive } \\
\text { theories of action } \\
\text { explicit }\end{array}$ & $\begin{array}{l}\text { Practitioners and researchers engaged in developing possible } \\
\text { avenues to address the problem based on their personal } \\
\text { experiences, observations and intuition. }\end{array}$ & \\
\hline $\begin{array}{l}\text { 3. Understanding the } \\
\text { problem and change } \\
\text { process }\end{array}$ & $\begin{array}{l}\text { Researchers conducted a needs assessment. Before and after } \\
\text { conducting the needs assessment, researchers lead the } \\
\text { consultation of the knowledge base to give theoretical } \\
\text { explanations about the patterns identified in the framing of } \\
\text { the problem and the needs assessment. The purpose was to } \\
\text { develop an understanding of the problem that is both } \\
\text { practice-oriented and theory-based, in order to provide } \\
\text { high-inference explanations of the problem of practice that } \\
\text { was being addressed. The next step in this third stage was to } \\
\text { understand the change process to comprehend the } \\
\text { environment in which the ACMHE would take place and the } \\
\text { activities and resources needed to promote change. With this } \\
\text { information in place, researchers and practitioners developed } \\
\text { a "theory of action" (Mintrop, 2016) - a plan that seeks to } \\
\text { address a specific problem of practice and promote changes } \\
\text { to improve educational practices. }\end{array}$ & \\
\hline $\begin{array}{l}\text { 4. Designing a } \\
\text { research based } \\
\text { intervention }\end{array}$ & $\begin{array}{l}\text { Once researchers and practitioners had developed a theory of } \\
\text { action, they designed and developed the curriculum. Before } \\
\text { implementing the fully designed intervention we conducted } \\
\text { quick trials or mini experiments in order to test the curricular } \\
\text { products and improve them before the first full } \\
\text { implementation. }\end{array}$ & $\begin{array}{l}\text { June } \\
2016- \\
\text { March } \\
2018\end{array}$ \\
\hline $\begin{array}{l}\text { 5. Implementing the } \\
\text { intervention and } \\
\text { collecting data }\end{array}$ & $\begin{array}{l}\text { Once the design was ready, and several iterations of the } \\
\text { curriculum had taken place, we implemented the } \\
\text { intervention. We collected process data during this stage. }\end{array}$ & $\begin{array}{l}\text { July- } \\
\text { November } \\
2018\end{array}$ \\
\hline $\begin{array}{l}\text { 6. Evaluating the } \\
\text { intervention and } \\
\text { deriving design } \\
\text { principles }\end{array}$ & $\begin{array}{l}\text { Finally, we conducted an evaluation of the implementation } \\
\text { and from the lessons learned and outcomes documented, we } \\
\text { (Pacheco and Murphy-Graham) developed design principles } \\
\text { to guide similar interventions in other contexts. }\end{array}$ & $\begin{array}{l}\text { November } \\
2018\end{array}$ \\
\hline
\end{tabular}

work stemmed from previous in-depth qualitative research in rural Honduras that investigated the circumstances and processes that led to child marriage (see MurphyGraham \& Leal, 2015).

From June 2016 to March 2018, we developed several versions of the curricular products, which consisted of three workbooks (two for students and one for parents). After piloting these workbooks (which involved a continuous collaboration with Bayan staff, teachers, students, and parents), we began our prototypical implementation, which refers to the stage of testing and adjusting the intervention while in practice (Mintrop, 2016). The first prototypical implementation took place in 21 
schools in the Department of Atlántida on the North Coast of Honduras from June to November 2018, and reached a total of 1200 students from 7th to 11th grade. During this prototypical implementation of the curriculum, from June to August 2018, we collected the process data that included $21 \mathrm{~h}$ of class observations in five schools.

In November 2018 (at the end of the school year, when students finished studying the curriculum), the UC Berkeley team conducted an evaluation to examine if the curriculum elicited the desired learning outcomes. During this assessment phase, data were collected via post-intervention interviews with 58 students from 7 th, 9th, and 11th grades (36 female students and 22 male students), 20 teachers from 7 th, 9th, and 11th grades (13 male teachers and 7 female teachers), and 18 parents (3 fathers and 15 mothers) in all 21 participating schools. Table 10.2 describes the gender and number of students per grade that participated in the interviews.

The instrument developed for the student interviews consisted of scenarios that were relevant to child marriage and intended to examine key concepts studied through the curriculum. These concepts were guided by, and aimed to address, the problems identified during the first three phases of this study. Each scenario was followed by a set of questions that was designed to examine if and how students used the knowledge and skills that they ideally acquired by studying the workbooks. The scenarios were crafted to reflect situations that students experience or witness in their lives and communities. The questions were developed in a way that students had opportunities to provide a rationale for their answers. The full results are described in Pacheco Montoya (2019). In this chapter, we focus on the analysis of the process data (observations) and the interviews related to learning outcomes (with students and teachers) described above.

\section{Data Analysis}

All observations were audio-recorded and field notes were also taken during these observations by researchers. The focus of these observations was to capture interactions between students that could provide evidence of the desired dialogues/discussions (e.g., discussions around social norms, evidence of cognitive dissonance, etc.) intended to be fostered by the curriculum. During the data analysis "codes" (Miles et al., 2014, p. 72) were used to categorize, organize, and find patterns in the data.

Table 10.2 Gender and grade of students interviewed

\begin{tabular}{l|l|l|l}
\hline Grade & Number of female participants & Number of male participants & Total \\
\hline 7 th & 12 & 9 & 21 \\
\hline 9 th & 11 & 5 & 16 \\
\hline 11 th & 13 & 8 & 21 \\
\hline Total & 36 & 22 & 58 \\
\hline
\end{tabular}


To create the codes, both deductive and inductive coding were used (Miles et al., 2014). The codes captured emotion (students' experiences, reactions, and sentiments) and values (participants' tenets, attitudes, and beliefs). Additionally, analytic memos were written about key class observations.

All interviews were audio-recorded and later transcribed. Categorical codes related to key ideas, such as gender equality, were created for each scenario. For instance, one scenario depicts two siblings who are treated in different ways. In this scenario, depending on the answers provided by participants, the answers were coded as "able to identify gender inequality" or "unable to identify gender inequality". A code that emerged (i.e., an inductive code) was "justifies as protection" and was added to the coding system. These responses were then tallied to generate numerical results for each question of each scenario.

\section{Understanding Child Marriage in Rural Areas of Honduras Through the Identification of Problems That Cause Child Marriage}

As a result of the needs assessment conducted during the third stage of this DBR study, we identified eight main issues that needed to be addressed in order to develop a curriculum aimed at preventing child marriage in rural areas of Honduras ${ }^{3}$ :

1. The prevalence of gender inequality in families and society at large.

2. Lack of awareness about the biological, psychosocial, and cognitive changes that occur during adolescence.

3. Adolescents are not aware of the consequences of child marriage and hold false beliefs about child marriage.

4. Adolescents engage in impulsive decision-making processes regarding romantic relationships.

5. The prevalence of unhealthy romantic relationships among teenagers.

6. Community members, parents, and students are not aware of the legislation that protects bodily integrity, particularly of minors.

7. There is limited knowledge and access to sexual reproductive health (SRH) resources.

8. Conflict at home and/or poor communication between parents and children are common.

In this chapter we focus on how the curriculum addressed problems 1 and 4, or issues related to gender inequality and adolescents' impulsive decision-making

\footnotetext{
${ }^{3}$ Again, we focused on the problems that can be addressed in a school-based setting. We acknowledge that there are structural causes such as poverty that cannot be adequately addressed in an educational context.
} 
Table 10.3 Causes of child marriage in rural areas of Honduras and HEY's related goals for prevention

\begin{tabular}{|c|c|c|}
\hline Problem & Brief description & Goal of HEY! \\
\hline $\begin{array}{l}\text { The prevalence of } \\
\text { gender inequality in } \\
\text { families and society at } \\
\text { large. }\end{array}$ & $\begin{array}{l}\text { Girls are not treated equally to their } \\
\text { male counterparts in their families } \\
\text { and communities, especially in terms } \\
\text { of mobility and socialization } \\
\text { opportunities. } \\
\text { Girls have limited economic and } \\
\text { academic opportunities. } \\
\text { Girls see marriage and motherhood as } \\
\text { their most worthwhile role. }\end{array}$ & $\begin{array}{l}\text { Change attitudes, beliefs, and } \\
\text { behaviors about unequal } \\
\text { gender norms. } \\
\text { Change attitudes beliefs, and } \\
\text { behaviors about what girls } \\
\text { and boys can do and be. } \\
\text { Inform students' decision- } \\
\text { making processes regarding } \\
\text { child marriage. }\end{array}$ \\
\hline $\begin{array}{l}\text { Impulsive decision- } \\
\text { making processes } \\
\text { regarding romantic } \\
\text { relationships. }\end{array}$ & $\begin{array}{l}\text { Girls exercise agency in their decision } \\
\text { to marry. That is, they are not being } \\
\text { forced to do so. } \\
\text { Girls elope with their partners } \\
\text { without being able to explain their } \\
\text { reasoning behind their decision. } \\
\text { These impulsive decision-making } \\
\text { processes are influenced by the } \\
\text { cognitive changes that individuals } \\
\text { experience during adolescence. } \\
\text { Girls are not happy about their } \\
\text { decision to elope with their partners } \\
\text { years later. } \\
\text { Girls elope with their partners } \\
\text { without knowing them well (short } \\
\text { courtship). } \\
\text { Girls see marriage as the only way to } \\
\text { engage in a romantic relationship } \\
\text { freely. }\end{array}$ & $\begin{array}{l}\text { Improving students' capacity } \\
\text { to think critically about } \\
\text { gender (in) equality. } \\
\text { Improving students' capacity } \\
\text { to think critically about their } \\
\text { future/ romantic relationships. } \\
\text { Expanding students' values, } \\
\text { beliefs, and experiences to } \\
\text { make informed decisions } \\
\text { about child marriage. }\end{array}$ \\
\hline
\end{tabular}

processes regarding romantic relationships. ${ }^{4}$ Table 10.3 describes problems 1 and 4 and the related goals of HEY!, which, broadly speaking, intended to improve the key life skills of critical thinking and decision-making.

\section{Brief Description of HEY!'s Curriculum Implementation Design}

HEY!'s curriculum consists of three workbooks: Living my youth with purpose (for students), Youth with equality (for students), and How to guide our young children (for parents), which were designed and developed collaboratively through several iterations (the workbooks are also discussed extensively in Pacheco-Montoya, 2019). These workbooks were written to respond to the eight problems identified in

${ }^{4}$ For a discussion of how the rest of these problems were addressed in HEY! see Pacheco Montoya (2019). 
the third phase of this intervention, as well as a theoretical framework developed to understand how these could be addressed. We followed a cascade approach for training SAT staff and students. The researcher/author ${ }^{5}$ coached SAT's district supervisors, who in turn trained tutors (the equivalent of teachers), who then trained 11 th graders. Eleventh graders implemented the curricular materials with 7 th and 9th graders. The purpose of implementing in three different grades was to reach students during two stages of adolescent development: early (10-13) and middle (14-17) adolescence (Steinberg, 2011). The goal was to address students before they reach critical ages (12-14 for 7th graders) as well as during those critical ages where adolescents are at greater risks of entering unions in rural areas of Honduras (15-18 for 9th and 11th graders; see Murphy-Graham et al., 2020). ${ }^{6}$ Students studied this curriculum in homogenous groups (classmates with similar ages and backgrounds, with the classmates that correspond to their grade) through a peer education system, using a pedagogical approach based on critical and feminist pedagogies (English and Irving, 2015; Freire, 2000; Shrewsbury, 1993). As a result of their study and interactive learning, adolescents will ideally be able to enhance their critical thinking and decision-making processes to make informed decisions about child marriage and will be empowered to overcome the constraints imposed by their socio-economic reality and limited choice set.

Previous studies have identified that peer education programs have difficulty sustaining positive outcomes over time (Agha \& Van Rossem, 2004). Other criticisms about peer-led programs include unequal power dynamics between peer educators and participants (e.g. gender dynamics) (Campbell \& MacPhail, 2002), lack of experience and knowledge compared to professional educators (Sriranganthan et al., 2012), and inadequate training (Walker \& Avis, 1999). This intervention addressed the lack of long-term behavioral change, inadequate training, and lack of experience and/or knowledge by using a longitudinal implementation approach. That is, students are exposed to the curriculum during a five-year period, and not during a single session/training. Students study the materials for the first time in 7 th grade and then again in 9th grade. When these same students are in 11th grade, they will be trained as peer educators in the use of the materials they already studied in 7th and 9th grades. This means that over time, students are exposed to the curriculum three times. There are distinct advantages afforded by this implementation/training design, including: (a) students are exposed to content relevant to the stage of adolescence they are in; (b) students will be exposed to this curriculum

\footnotetext{
${ }^{5}$ The workbooks Living my youth with purpose and How to guide our young children were written by Juanita Hernández, an author with decades of experience designing interactive texts for youth. The book Youth with equality was written by the co-author of this chapter, Diana Pacheco-Montoya. All books were written in collaboration with Bayan staff members, teachers, students, and parents. Each author conducted the training of the workbook(s) she wrote.

${ }^{6}$ Murphy-Graham et al. (2020) conducted a longitudinal study of adolescents in rural areas of Honduras and followed their life trajectories during adolescence. These authors found that by age $20,46 \%$ had entered a union at some point. Most of the growth in entrance into first union occurred from age 15 through age 18 .
} 
before and during the time they reach critical ages, when they are most vulnerable to child marriage and unhealthy relationships, and (c) it ensures that once students become peer educators, they will already be familiar with the content they facilitate. In this sense, through time, students become both recipients and implementers of the curriculum. Additionally, students are accompanied and supervised by teachers, who also undergo a training process. If students lack knowledge or need support, they can rely on the teacher to provide it.

\section{Understanding the Change Process: The Roles of Critical Thinking and Cognitive Dissonance}

In addition to understanding these causes of child marriage, we also needed to hypothesize how to create a learning environment and scaffold activities and resources to promote change. We developed a theoretical framework for fostering critical thinking related to gender inequalities and norms, drawing upon existing theory and research that helped clarify the key concepts and goals of the project. For example, we incorporated Brookfield's $(1997,2012,2017)$ work on critical thinking to develop HEY's curriculum. Assumptions play a central role in Brookfield's conceptualization of critical thinking. Assumptions are taken-for-granted beliefs which might seem commonsense until we think critically about them. Brookfield (2012) proposed three kinds of assumptions: causal, prescriptive, and paradigmatic.

Causal assumptions are explanatory and predictive. They explain cause and effect linkages. For example, someone might think that if they marry, they might have more freedom than what they have at home. Prescriptive assumptions refer to desirable ways of thinking and acting. For instance, individuals might hold assumptions that girls should be modest and submissive. Paradigmatic assumptions frame the way we understand and look at the world that surrounds us. These assumptions are grounded in dominant ideologies, or sets of practices and beliefs that organize the world and influence how we think and act, which are accepted by the majority as commonsense. Patriarchy, the system of society in which men hold the power and are thought of as superior to women, is an example of a dominant ideology. An example of a paradigmatic assumption linked with patriarchy is that boys are inherently better leaders than girls.

We reflect upon and make hundreds of decisions daily. However, most of these reflections and decisions are not critical; they are merely technical. We start thinking critically about our assumptions and our actions when we consider the social or political context, or when we reflect about power and hegemony (Brookfield, 2017). According to Gramsci (1971), hegemony refers to the process in which a dominant class establishes ideas, beliefs, and structures that benefits them. These set of values and beliefs are then viewed as natural and preordained by the majority of people and are thought to be good for everyone (as cited in Brookfield, 2017). For instance, one such belief is that men are more capable or smarter than women, and that is the 
reason why there are more men in positions of power. People come to internalize this oppression and becomes normalized: it comes to be "deeply embedded, part of the cultural air we breathe" (Brookfield, 2017, p. 16). As such, critical thinking has two main purposes: (a) understanding power relationships in our lives and redirecting the flow of these relationships, and (b) uncovering hegemonic assumptions, which are "typically paradigmatic" (Brookfield, 2017, p. 40). That is, assumptions one might consider to be in her best interest but actually harm her (Brookfield, 1997, 2017). According to Brookfield (2012), critical thinking encompasses: (a) identifying assumptions; (b) checking the accuracy and reliability of these assumptions; (c) listening to others' perspectives and opinions; and (d) and taking informed action. Because our intervention took place in a school-based setting, it is important to consider the social nature of critical thinking. Critical thinking is a social process where peers and teachers become "critical mirrors" through dialogue (Brookfield, 1997, p. 19). Being critical mirrors means that through dialogue, students have opportunities to reflect together upon assumptions that were taken for granted before. Having critical mirrors facilitates being exposed to new perspectives. Ideally, these new perspectives or ideas, removes them from their comfort zone and help them examine parts of their thinking that would otherwise remain vague, unclear, or obscure. Critical thinking is continuously emphasized as a goal of the SAT curriculum.

In HEY!, we wanted to support critical thinking specifically with regards to gender inequality and child marriage. The lessons created followed a similar pedagogical approach to the SAT curriculum, often starting and ending with questions and activities that encouraged discussion (for a more detailed description of the SAT curriculum, see Murphy-Graham, 2012). In addition to questions and discussions aimed at hunting for and checking assumptions, the curriculum includes the introduction of new concepts and ideas to aid in the critical thinking process, including "multiplicity of perceptions" and exposing students to alternative ideas and ways of thinking (Brookfield, 1997, p.19).

However, critical thinking in itself is not enough to change child marriage practices. Students can participate in a discussion that promotes critical thinking, study lessons that provide a multiplicity of perceptions, and still not experience a change of attitude or behavior. In an ideal scenario, critical thinking should also lead to cognitive dissonance (Festinger, 1962).

By cognition, Festinger refers to "any knowledge, opinion, or belief about the environment, about oneself, or about one's behavior" (1962, p. 3). Dissonance, on the other hand, refers to the unpleasant state that occurs when an individual is exposed to "two or more elements of knowledge that are relevant to each other but inconsistent with one another" (Harmon-Jones \& Harmon-Jones, 2012, p. 72). Festinger theorized that when an individual is confronted with this unpleasant state, this will motivate the person to engage in psychological work to reduce inconsistencies between cognitions. Cognitive dissonance is "an antecedent condition which leads to activity oriented toward dissonance reduction just as hunger leads to activity oriented toward hunger reduction" (Festinger, 1962, p. 3). Cognitive dissonance is measured through attitude change. As such, one of the main objectives of HEY! 
is to change attitudes and beliefs of students about child marriage and its causes, which can ultimately inform their decision-making processes. For critical thinking and ultimately cognitive dissonance around gender equality and child marriage to happen in the classroom, students need an environment where they are allowed to examine, question, and reconsider their assumptions about these issues. Students need a space where critical thinking is championed. To create this learning environment, we drew insights from critical and feminist pedagogies.

\section{Pedagogies to Support the Incorporation of Critical Thinking and Cognitive Dissonance in the Classroom}

We followed Giroux's (2004) definition of pedagogy, which emphasizes the need to address power relations and representations of the self and the social environment in the learning process. To develop curricular materials that addressed issues of power, inequality, and social change, this intervention drew upon critical (English \& Irving, 2015; Freire, 2000) and feminist (Shrewsbury, 1993) pedagogies to design, develop, implement, and evaluate HEY!. Critical pedagogy establishes that education should be used to promote emancipation from oppression through the emergence of a critical consciousness. To achieve critical consciousness, or conscientização, a deep awareness of one's reality, the learning process should be guided by dialogue and critical thinking. In order to achieve radical changes in society through education, it is necessary to "develop forms of critical pedagogy capable of appropriating from a variety of radical theories" like feminism (Giroux, 2004, p. 32). Because the focus of HEY! is to address the causal factors of child marriage by challenging the social norms that perpetuate gender inequality, critical pedagogy is paired with feminist pedagogy. According to Shrewsbury (1993), "at its simplest level, feminist pedagogy is concerned with gender justice and overcoming oppressions. It recognizes the genderedness of all social relations and consequently of all societal institutions and structures" (p. 9). Feminist pedagogy, consistent with the conceptual framework of SAT, views the classroom as a mutualistic environment where students become a community of learners who engage in a reflective process to promote social change. These key ideas, shared between the team at UC Berkeley and Bayan, informed the design, implementation, and evaluation of HEY!. Following these two pedagogies, the workbooks include the discussion of important concepts and case studies that promote an awareness around issues of power and inequality associated with gender relations. They also include questions at the beginning, middle, and end of each lesson aimed at promoting group discussions and reflections that invite students to analyze their personal and social realities and their role in promoting social change. 


\section{Examining Critical Thinking and Cognitive Dissonance During and After the Implementation of HEY!}

After students studied the HEY! materials, we examined if and how critical thinking and cognitive dissonance occurred during and as a result of the implementation of HEY!'s curriculum through classroom observation and in-depth interviews (see Stage 6 in Table 10.1). We also explored if and how critical and feminist pedagogies supported critical thinking during the implementation of the curriculum. The following tenets informed our assessment of critical thinking for these purposes: (a) it should be locally crafted and context specific; (b) peers can participate in assessment as they act as critical mirrors; and (c) assessment should allow learners to demonstrate and justify their engagement in critical thinking (Brookfield, 1997).

\section{Dialogue, Critical Mirrors, and Re-examining Assumptions}

During the interviews, we asked teachers (who accompanied 11th graders during implementation) if they thought the workbooks were successful in eliciting discussions that promoted critical thinking and social analysis. Most of the teachers thought this was the case, particularly around discussions of gender equality. They provided concrete examples, including:

Interviewer: What themes generated rich conversations among students?

Teacher (Male): It was the lesson about gender equality. As I mentioned to you before, some say that girls can't play soccer, because we see that only boys get to play soccer, no girls at all. We saw that boys had a machista attitude and it is clear that it comes from dynamics at home that promote it. For example, men work in agriculture and do not help to clean, wash dishes, or mop the floor, and they have more freedom and girls have no freedom. So, the girls in some way stood up for themselves, they said that they also worked and deserved the same rights.

When another teacher was asked whether he believed these texts were useful to students, he shared that students not only changed their attitudes and beliefs but their behaviors as well:

Interviewer: Can you give me an example of something you have observed/ listened from students or parents that makes you think this intervention is helping prevent child marriage or change behaviors?

Tutor (Male): Mostly with things related to equality. I have a student that always said that "girls have to do this, and boys have to do that." He had this marked division girl/boy, boy/girl. But now he has understood. For instance, before he would not help with cleaning the 
classrooms. He would take the trash out, but he wouldn't touch a broom or a mop. He thought that was something for women. $\mathrm{He}$ would rather do chores that required strength. But now it's different. We are all astounded. Now he is the first one grabbing the mop... I feel that he understood what the norms to live in society are.

As noted by these teachers, the workbooks provided an opportunity for students to recognize their positionality and how they were affected by gender inequality and/ or how restrictive notions about gender norms affected their behaviors. Students had the opportunity to engage in a series of discussions that allowed them to uncover power dynamics and hegemonic assumptions around gender norms. This process of uncovering assumptions about the role of gender norms required a social context (in this case the SAT classroom) where individuals could be exposed to different viewpoints, a context where individuals' assumptions were mirrored through others. For instance, lesson 6 of the workbook Youth with Equality, "Our lives during and after puberty," describes how the biological changes that adolescents experience during puberty intersect with youth's emotions and the expectations society has for them. The lesson contains a table where students are expected to describe two biological changes that take place during puberty, two emotions or feelings they experience during puberty, and two ways in which societal expectations during puberty are different for boys and girls. During this exercise, two female 11th graders, Melissa and Victoria, ${ }^{7}$ discussed how the beliefs around condoms reflected unfair expectations for girls and boys. During this discussion, a male 9th grader, Juan, intervened and his comments reflected commonly-held beliefs that girls had no business carrying condoms:

Melissa (11th): Nowadays, if a person sees that a boy is carrying a condom, they tell him "buy more," "you're the man!" But if they see a girl carrying a condom...

Victoria (11th): They start judging her.

Melissa (11th): They start saying "who knows how many more she has bought before, how many more she has used before." But they do not say that about a boy.

Then Juan, implying that girls should not carry condoms, asked:

Juan (9th): Then, why is she carrying them? [The condoms]

Melissa then tried to challenge his comments by asking why would he carry a condom (pointing out that condoms are for sex, whether you are a boy or a girl). He evades this question with a joke:

Melissa (11th): Let's see, if you carry a condom, what do you carry it for? Juan (9th): Just to carry it around.

(students laugh)

\footnotetext{
${ }^{7}$ All names used are pseudonyms.
} 
Melissa (11th): Well, a woman can carry a condom just for the sake of carrying it as well.

\section{(silence followed by laughter)}

Teacher (F): This is where the machismo becomes apparent.

Melissa (11th): Yeah, that is gender inequality! Because they treat the boy as if he were a champion if they date many girls. And sometimes if a girl has several admirers, they call her a ...

Victoria (11th): Boys can have many female friends but girls can't have male friends.

Juan (9th): $\quad$ No

In this exchange, Juan's interjections reflect the belief that girls have no business carrying condoms, and he does not seem to indicate that his belief is subject to change. However, what is important in this exchange is how dialogue around the differential treatment of girls and boys took place in the classroom. Juan's peers and teacher responded and reflected on the views that he accepts as normal or acceptable (i.e., the hegemonic assumption, grounded in patriarchy, that only men should carry condoms). This kind of exchange is crucial in uncovering how one's assumptions about a subject might be questionable: a further examination about the assumption can help lead to a broader understanding of the subject. In this exchange, dialogue played a central role as it allowed peers to become critical mirrors of Juan's assumptions (and everyone participating in this discussion). This exercise is an example of how the workbooks, guided by elements from critical and feminist pedagogies, generate activities and discussions. These provided students like Juan with the opportunity to engage in a collective reflective process that enabled them to become aware of their own assumptions and develop a greater awareness of the society in which they live.

Another example of dialogue that allowed assumptions to be uncovered occurred during a training of 11 th graders. A male student, Mario, expressed the common notion in these communities that labels girls "locas," meaning that they are acting "crazy," "easy," and/or too "flirty." The HEY! workbook generated a discussion about the role that puberty plays in behavioral changes of adolescents and why terms like these should not be used to describe girls' behaviors. This exchange shows how the text "Puberty, teen pregnancy, and child marriage", from Youth with Equality, provided a new framework to understand these behaviors:

Mario (11th): Teacher, there is an interesting relationship between puberty, pregnancy, and marriage. Well, thanks to puberty, that girl is around acting like a "loca."

Teacher 1 (F): Do you think it is appropriate to say that a girl is acting like a "loca."

Julio (11th): 2: No. She's acting crazy.

Teacher 1 (F): Why do you think she behaves like that? Because she is in that phase, because we like to judge others and say that girls are acting like locas but it is not that they want to act inappropriately. 
Mario (11th): It's thanks to puberty.

Teacher 1 (F): She is simply going through changes that you have already studied. You need to know how to approach this with the younger students. You can't make them uncomfortable saying "these girls are acting like locas.". We know what is behind all of this, girls go through changes... and maybe because of lack of knowledge people interpret it in a wrong way like your classmate here. That is not the right way, girls and boys have behavioral changes because they are going through biological changes...we should not say inappropriate things like she's acting like a loca...We should help them, help them understand what is happening with their bodies.

At the end of the discussion of this lesson, the two teachers who were training the 11th grade students explained that they should not use these pejorative terms and that they should instead help younger students understand why these behavioral changes happen. The conversation continued:

Teacher $2(\mathbf{M})$ : So, what are you going to say if your see a girl that is starting to like boys and she is only 14 years?

Mariana (11th): That she is going through puberty.

Pedro (11th): That it is a normal thing in adolescents like her.

Teacher 2: $\quad$ Correct. It is a result of a process she is going through.

Carla (11th): That her hormones are going crazy.

Teacher $1(\mathbf{F})$ : Exactly. It is a process.

Teacher 2 (M): In that moment she feels attraction towards boys, and hormones are the cause of that attraction. Do you think sexual appetite is greater or less?

\section{1th grade students (collective response): Greater.}

Mario inadvertently repeated a common notion that stigmatizes girls' behaviors. It was a prescriptive and hegemonic assumption (i.e. that girls should behave in a certain way and any deviation is unacceptable) that reflects not only gender inequality, but also a deep misunderstanding of the changes that youth experience during adolescence. Mario was able to reassess his assumption after his teachers and other peers elaborated an alternative way of understanding those behaviors.

In addition to recognizing and challenging assumptions around gender inequality, the workbook also invites students to imagine alternatives to the reality that they experience. The following exchange was captured during a peer implementation between 11th graders and 9th graders of lesson 3 of the workbook Youth with Equality, "Gender (in)equality." The following exchanges are excerpts that took place throughout the one-hour class discussion of this lesson:

David (11th): Can somebody tell me what gender inequality is?

Jessica (9th): When men and women do not enjoy the same rights.

David (11th): Can someone give me an example of gender inequality?

Francisco (9th): An example can be when either a boy/girl has a preference to go to school over a girl/boy. 
The conversation continued:

David (11th): Some examples of gender norms are "men can't cry because they are men...or can't sweep because he is a man, can't do laundry because he is a man." Those are gender norms. Where are these gender norms applied?

Rosa (9th): In the family, at home, in society.

The peer tutor then invited 9th graders to reflect about where gender inequality can be practiced:

David (11th): Where should we practice gender equality?

9th grade students (collective response): In our families, our homes, in society.

David (11th): Where else?

Rosa (9th): Everywhere!

David (11th): Wherever we go, it is important that we practice gender equality. At work, in our families.

Martha (9th): At school.

David (11th): Do you think this [gender inequality] happens amongst friends? 9th grade students (collective response): Yes.

The peer tutor continues to read the reflection questions included in the lesson:

David (11th): $\quad$ (Reading from the workbook) How can boys contribute to gender equality?

Dennis (9th): Sweeping, helping out at home.

Tania (9th): $\quad$ Practicing gender equality.

David (11th): What else?

Pablo (9th): $\quad$ Not being machistas!

David (11th): $\quad$ Men can contribute by setting a good example.

The discussion ended with a reflection about the impact that gender equality could have on society:

David (11th): If gender equality changes are achieved, who will they affect?

Paola (9th): $\quad$ Our kids, future generations.

Bessy: (9th): Society.

The classroom dialogue captured here illustrates how, through the use of strategic questioning, the curriculum pushes students to recognize and challenge inequality. It also provides students with an opportunity to reimagine and propose alternative ways in which they can promote and achieve gender equality. Importantly, following a feminist pedagogy, the workbook pushes this analysis beyond the walls of a classroom and invites students to analyze how gender equality might not only improve their lives, but society overall, and how they can become agents of change. 


\title{
Assessing Critical Thinking Through Scenarios
}

We developed a scenario-based interview instrument to assess students' ability to use key concepts and knowledge learned through the curriculum, as well as their ability to think critically (in this section we discuss the scenarios related to gender inequality only, and there were other scenarios in the instrument discussed in Pacheco Montoya, 2019). These scenarios were based on stories or experiences that we have documented over a decade of research in these communities. As such, they reflected the context that students experience in their daily lives. The first scenario described two siblings, María and Juan:

\begin{abstract}
María and Juan are siblings. María is 16 years old and Juan is 15 years old. Their parents treat them very differently. Juan is allowed to go out freely to play and spend time with his friends. María can rarely leave the house and have fun. Juan has a girlfriend and the whole town knows about it and approves. Last year, María had a boyfriend without her parents knowing. Her neighbors found out, and started calling her "slutty." The neighbors are always criticizing María for the way she dresses, or if she hangs out with boys. She feels surveilled. Juan doesn't worry if others approve of his behavior or not.
\end{abstract}

(a) Why do you think that these differences exist in how men and women are treated?

(b) Do you agree that they should be treated differently? Why/why not?

In the interviews, $73 \%$ of the 58 participating students identified gender inequality as the reason why María and Juan were treated differently, 20\% were not able to explain conceptually why these differences existed, and only $7 \%$ explained that they justified this scenario given that girls needed to be more protected (a well-established belief in these communities). Eighty-nine percent of the students disagreed with this differential treatment while $11 \%$ did not find a problem with it. Below are some sample responses:

Fernanda (7th): Well, maybe because the father thinks that only women do incorrect things, so they treat her with gender inequality. The father thinks that the boy only goes out to play with classmates and friends, men have vices as well, they can learn and do wrong things... The father doesn't let the girl go out because he thinks that she will be with a man or something like that when in fact, some girls actually get married because they don't let them go out.

José (9th): There's no gender equality, it should be equal. If the boy goes out, the girl should go out too, and both have to have fun, not just the boy while the girl is at home like a slave. I think there shouldn't be inequality, both of them should have fun.

Fernanda's response suggests that she was able to uncover the assumption of the father in the scenario (note she says "father" although the scenario mentions "parents"). Fernanda's response reflects a common causal assumption in these communities: if you are a girl, you need to be protected and your mobility limited, because if not, you will wind up pregnant or harmed. She is able to dismantle the assumption that girls are the only ones that need to be protected, and points out that boys can also 
encounter danger outside the home - an argument that is not discussed in the workbooks, and therefore we can assume is a result of her own analysis or a result of something she learned during class discussions. She then continues to make a connection between the lack of freedom and girls' decisions to elope. That is, she is making a direct association between gender inequality and child marriage. It is important to note that she is not necessarily legitimizing this decision, but rather explaining how treating girls unfairly can inform girls' decision or contribute to their desire to leave their home, pointing out negative consequences of gender inequality.

José, a ninth grader, also revealed an important behavior in his response: he rejected gender inequality even when his position as a male allowed him to benefit from this differential treatment. He energetically condemned girls' lack of opportunity to have fun, and he connected this situation to the burden of housework that falls upon girls (describing it as slavery). He advocated for equal treatment. Importantly, both responses used the concept of gender inequality to explain their reasoning and demonstrated a deep understanding of this concept. However, they did not simply regurgitate "gender equality" in their response. Instead, they offered critical insights regarding why this happens and why it is wrong, demonstrating their capacity to use a concept and apply it in a practical and meaningful way. Over four lessons, the curriculum provided students with facts and information about gender inequality that influenced their reasoning. As shown in these responses, this information was coupled with their ability to critically analyze these scenarios.

The second scenario described tensions in a family due to the fact that family members do not think that men should do housework that is thought to be a woman's job:

Lourdes has a husband named Alexis. Alexis has a small cornfield in which he works in the mornings. Lourdes is a SAT teacher and works in the afternoon. When Lourdes goes to work in the afternoon, Alexis takes care of their children, helps cleaning the house and makes dinner. Alexis' mom and brothers don't like that he does "women's stuff" and they are bothered that Lourdes is not taking care of the things that Alexis has to do, because they think that taking care of the home and children is not a man's job.

Ninety-eight percent of the 58 students that were interviewed said they disagreed with this scenario. Fifty percent of students were able to explain this scenario through the concept of gender norms. Thirty-four percent of students explained this scenario using the concept of gender inequality, which is also a fine response but not as specific as gender norms. Fifteen percent of students were unable to provide an explanation for why they disagreed with it. Many students explained how socialization played a role in these beliefs. For example, Carlos, a 7th grade male student explained that these beliefs form due to gender inequality during socialization:

Carlos (7th): That happens because they don't teach them when they are young what gender equality is. That's why they think men can do certain things and women can't, and it's not like that. Both have the capacity to do the same things.

Finally, almost $90 \%$ of students reported they would challenge Alexis' family members' resistance to his behavior. Gabriela, a 7th grade female student stated that she would tell Alexis' family that "if women can take care of the home, men can too." 
As shown by the responses above, students were able to use key concepts to explain and justify their responses. They were able to (a) identify their assumptions; (b) check their assumptions through dialogue with their peers and teachers; (c) be exposed to different perspectives using their peers as critical mirrors; and (d) imagine alternatives to the reality that sustains hegemonic views. One noteworthy accomplishment is that HEY!'s curriculum has provided a context in which boys were able to develop a greater awareness of the importance of gender equality and develop attitudes that are conducive to more equitable relationships (see also Sahni, Chap. 9, this volume). This is a salient result given that many interventions do not include boys or examine boys' attitudes towards issues such as gender inequality or child marriage (CEFM and Sexuality Programs Working Group, 2019).

\section{Experiencing Discomfort and Hope: How Critical Thinking Can Lead to Cognitive Dissonance}

During interviews, several students stated that gender inequality was one of the most relevant topics for their lives and reported changing the ways they viewed themselves and what they were capable of doing. For instance, Javier, a male student, described how HEY! made him confront his previous beliefs about gender inequality:

Javier (11th): $\quad$ Of course, gender equality as well because women are valuable too. I was taught to have a machista attitude.

Interviewer: Who taught you to be machista?

Javier (11th): My dad

Interviewer: What would he say?

Javier (11th): Well, my dad used to say that women are here to serve and that a man's obligation is to be the head of the home and only men's ideas are valid. Women should not have a voice or dictate what should happen. As I was learning, I understood that I should not have those attitudes.

Interviewer: So, the content in the text collided with what you believed?

Javier (11th): Yes, it collided a lot. It became a controversy.

Interviewer: During the class or for yourself?

Javier (11th): $\quad$ For me.

Interviewer: What was the controversy?

Javier (11th): Why should I serve a woman?

Interviewer: That was your dad's voice.

Javier (11th): $\quad$ Yes, my dad's voice was there but that started to fade away and I was able to see that it was good to be equitable.

The unpleasant state that Javier experienced when he was exposed to new information that challenged previous knowledge is an example of "dissonance" (Harmon 
Jones \& Harmon Jones, 2012). As Javier explained, he engaged in a psychological work (an internal "controversy") to reduce the inconsistencies of these two views. In the end, he was able to clarify his new standpoint on gender equality. Javier was able to identify the unfairness in the power dynamics between men and women into which he was socialized.

Other students reported changing their views about themselves and who they could become. For example, a 7th grade student, Mercedes, reported that learning about gender equality helped her believe that she could do anything because she has the same capabilities as boys:

Mercedes (7th): I used to think that we women had fewer rights than men.

Interviewer: Why did you think that?

Mercedes (7th): I thought we were weaker...

Interviewer: Can you give me an example?

Mercedes (7th): When I used to see my cousins play soccer, I would see them and think I could not do what they were doing, I felt underestimated because they could play, and I couldn't.

Interviewer: Why? Because they were given permission to play or because they were stronger?

Mercedes (7th): Because they were stronger...

Interviewer: And now that you read these things, what do you think?

Mercedes (7th): That when I see someone doing something, I feel that I can also do it because we are equal, and we have the same capabilities.

Mercedes was able to challenge her own hegemonic assumptions - of her inferiority because she was a girl, and she was naturally weaker than boys - and reimagine what she was capable of. Her response shows that Mercedes now has a framework to understand, explain, and reject gender inequality, and to recognize her inherent worth, a key component of empowerment (Murphy-Graham, 2012). Mercedes' account suggests that she experienced cognitive dissonance as a result of the lessons, and that she was exposed to a new set of beliefs that were different to those she held before participating in HEY!.

Vignettes, based on real-life, contextually relevant scenarios, that were included in the curriculum were instrumental in helping students expand their knowledge about gender. In one of our interviews, an 11th grade student, Michelle, made reference to vignettes included in lesson 2 in the text Youth with Equality. One vignette tells the story of "Freddy," a young man who is a chef, which challenges the cultural norm of men staying out of the kitchen. The second vignette is about "Dunia," a girl who always wanted to become a soldier. Despite her family and friends telling her that only men can be soldiers, she was able to make her dream come true. From Michelle's response, we see evidence that the vignettes helped to informed her analysis and interpretation of what men and women can do:

Michelle (11th): I really liked the lesson about gender. It explains that women and men should have the same rights...It also teaches us that just because someone is a woman, it does not mean that she can't do 
things that men do and vice versa... For example, a man can cook, not just women. There are men who are cooks that are (professional) chefs. A woman can be a soldier, a president, things that are supposed to be restricted to men. Women can also do those things.

Interviewer: So before reading these lessons, you thought that those things were restricted to men or did you know that you could be a soldier, for example?

Michelle (11th): No.

Interviewer: You did not imagine this could happen? What did you think of these stories?

Michelle (11th): I like them because they taught me that one can achieve things if one desires.

Michelle's response suggests that she had accepted as normal and commonsense that there were certain professions and leadership roles that were exclusive to men. The vignettes helped her challenge these views and reconsider what women are capable of doing. Vignettes that attempted to provide positive and negative social images about gender inequality and child marriage were always accompanied with a discussion that promoted dialogue and critical thinking, as well as activities to further the analysis of important concepts such as gender norms. For example, the vignettes described above are followed by the questions:

(a) What lessons do Freddy and Dunia teach us?

(b) What role did family members play in helping Dunia and Freddy challenge traditional gender norms so that they could reach their dreams?

(c) After studying this lesson, what would your reaction be if someone tells you that you cannot do something because you are a boy or a girl?

The curriculum helped Mercedes and Michelle realize that they are capable of doing things regardless of their gender such as playing soccer or becoming a president.

The responses of students in these three examples suggest that a curriculum can provide students with opportunities to recognize hegemonic assumptions, understand the context and dynamic of power relationships, create opportunities to reconsider their beliefs, and provide hope that things can be different and that they have capability to become who they desire. These three examples also offer an opportunity to examine the different ways in which girls and boys experience cognitive dissonance. Javier, the student who reported experiencing cognitive dissonance, struggled in letting go of the comfort that male privilege provided him. The discomfort stemmed from accepting that he needed to let go of being waited on by women and being the only one who made decisions. Ultimately, he concluded that giving up the comfort that inequality provided him was the fair thing to do. On the other hand, girls' experiences (like Mercedes and Michelle) were less uncomfortable and more enlightening. For girls, studying HEY! provided them with reassurance and a newfound sense of possibilities. As Brookfield (2017) mentions, it is common for 
individuals to experience initial resistance to examining hegemonic assumptions critically, "but when they are challenged and changed, the consequences for our lives are explosive" (p.18).

\section{From Class to Life: How Can Studying HEY!'s Curriculum Influence Students' Decisions and Actions?}

Our interviews did not examine behaviors or change of behaviors. We did not directly ask about the decisions that students have made since being exposed to the curriculum. However, during our interviews, some students reported instances where their experience with the curriculum informed their decisions and behaviors. The following examples do not intend to show or claim an impact of this intervention. Instead, what follows provides evidence that the curriculum can inform adolescents' decision-making processes and actions regarding gender inequality and child marriage, and we give examples of students' desired outcomes.

The first case is that of Martha, an 11th grade female student. She shared that after being exposed to HEY!, she was able to realize her worth and her right to be treated equally to men. As a result, she confronted her parents and encouraged them to treat her and brothers with equality:

Martha (11th): We are six sisters and two brothers. My parents always used to say that I better study because they would only leave me the house as my inheritance. They used to say that the land was for my brothers because they were able to work, because they were capable of working the land, and we girls could not do that. So, I read to them the content of the workbook where it said that girls and boys have the same rights because we are capable of doing any kind of work. As a result, they changed their attitude towards me. I believe they love all of us equally now. I have also told some of my friends that they should respect their girlfriends. If their girlfriends turn around, they are already flirting with other girls. I tell them that that is not respect, it is not love. I have learned all these things through the workbooks.

Another example is that of Xiomara, an 11th grade female student. During her interview she shared that she changed her mind about eloping with her boyfriend after studying the workbooks. She explained that the social images she was exposed to during this intervention informed her decision:

Interviewer: Can you tell me about something specific that you might say changed after studying these workbooks?

Xiomara (11th): I changed my decision to marry. I was thinking about getting married and after studying these workbooks I retracted [from getting married]. 
Interviewer: Tell me about this process, what things made you change your mind?

Xiomara (11th): So many things, the workbooks included some dramas, some case studies including one of a girl who decided to marry and she did not like it and that is not worth it.

Interviewer: So, you got scared?

Xiomara (11th): Yes, I do not want anyone telling me I cannot go out. I like my freedom.

Interviewer: Do you think you did the right thing?

Xiomara (11th): Yes. I did the right thing. In my house I have everything I need.

Interviewer: Do you think you would have eloped if you had not studied these workbooks?

Xiomara (11th): I would probably have; I am not sure.

Finally, a teacher reported that one of his students, Rosa, was thinking about getting married, but after being exposed to HEY!'s curriculum, she changed her mind:

Teacher (M): One of my students told me that she had plans to drop out. When I asked her why, she said "I have too many problems at home. They are not helping me economically to pay for my education expenses so I think I will marry or I will leave to San Pedro Sula to work." So I told her "you should think about it because I do not think that what you are planning to do will make your situation better. In fact, it might make it worse." After the workbooks came [to our school], she was one of the students that was involved the most in this project. Afterwards, she told me, "I will not drop out, I will see how I can get a part time job in the area so I can buy the books for school, I will keep studying." The day we finished implementing the workbooks she posted on Facebook things she had learned and how what she learned had changed her.

The stories shared by Martha, Xiomara, and Rosa's teacher suggest that adolescents are using this knowledge to think critically about issues of power in gender relations and to consider other alternatives to child marriage. Xiomara, for example, reported not wanting to experience the consequences of child marriage as depicted in the vignettes. Martha decided to act against the inequality she was experiencing, based on the knowledge and information she learned through the workbooks. Furthermore, Rosa's case suggests that HEY!'s curriculum might be helping to address false beliefs about child marriage as an option when things at home are tense or when the economic circumstances are difficult. In short, our results suggest that participants' decision-making processes are being influenced and informed both by the knowledge they have gained through HEY!'s curriculum and their newly cultivated capacity to think critically. 


\section{Conclusion}

Adolescents around the world are often forced to make difficult life choices. It is crucial that educational systems equip them with the necessary life skills to make well-reasoned decisions, especially in contexts with limited choice sets, such as rural Honduras. A crucial life skill and component of decision-making is the ability to think critically. Being able to make decisions and take actions that are based on the ability to understand and analyze critically the world that surrounds us is of utmost importance. The point of critical thinking is to "take informed action... We think critically not just to survive, but also to live and love well" (Brookfield, 2012 p.13). Thinking critically can help adolescents live more satisfactory lives, lives in which decisions and actions are not arbitrary, but well-reasoned.

Promoting social norms that reflect gender equality and disrupt child marriage in an educational context is a challenging endeavor. In this chapter, we provided an empirical example of how a school-based intervention addressed these issues. This study provides important insights into how critical thinking, as a life skill, can be incorporated into curriculum and pedagogy to address gender inequality and prevent child marriage.

Addressing gender inequality and child marriage requires a careful incorporation of pedagogies that foster social analysis, assess and change power relations, promote critical thinking, and challenge oppression. As described in this chapter, critical and feminist pedagogies provide a pedagogical framework to incorporate these components in the classroom. The implementation of a curriculum should also follow principles of critical thinking, which include the examination of hegemonic assumptions and the opportunity to imagine alternatives ways of thinking and acting. To achieve this, the classroom should create a community of learners who act as critical mirrors, guided through and by dialogue. It is crucial that boys and girls participate in this process. Ideally, an educational context that allows and teaches students to think critically will lead students to experience cognitive dissonance and also support them in making sense of these inconsistencies (Harmon-Jones \& Harmon-Jones, 2012). In the case of HEY!, students experienced cognitive dissonance about beliefs they were socialized into, like gender inequality, and made sense of their feelings by learning through the curriculum.

The results of this study suggest that gaining critical thinking skills is an achievable and powerful process that encourages boys to recognize and challenge gender inequality. At the same time, the learning process provides girls with opportunities to reimagine their roles and worth. While our initial results are quite positive, we do not yet have the ability to conduct a rigorous study on the impact of HEY! on rates of child marriage and teen pregnancy. We hope to be able to eventually document the processes and impact of HEY! on a variety of outcomes, including behavioral outcomes. In the meantime, the case of HEY! can inform the design and implementation of like-minded programs to foster critical thinking as a life skill for youth in other contexts. 


\section{References}

Agha, S., \& Van Rossem, R. (2004). Impact of a school-based peer sexual health intervention on normative beliefs, risk perceptions, and sexual behavior of Zambian adolescents. Journal of Adolescent Health, 34(5), 441-452.

Ahearn, L. M. (2001). Language and agency. Annual Review of Anthropology, 30(1), 109-137. https://doi.org/10.1146/annurev.anthro.30.1.109

Anderson, T., \& Shattuck, J. (2012). Design-based research: A decade of progress in education research? Educational Researcher, 41(1), 16-25.

Bongaarts, J., Mensch, B. S., \& Blanc, A. K. (2017). Trends in the age at reproductive transitions in the developing world: The role of education. Population Studies, 71(2), 139-154. https://doi. org/10.1080/00324728.2017.1291986

Brookfield, S. D. (1997). Assessing critical thinking. New Directions for Adult and Continuing Education, 1997(75), 17-29. https://doi.org/10.1002/ace.7502

Brookfield, S. D. (2012). Teaching for critical thinking: Tools and techniques to help students question their assumptions. Jossey-Bass Publishers.

Brookfield, S. D. (2017). Becoming a critically reflective teacher (2nd ed.). Jossey-Bass Publishers.

Campbell, C., \& MacPhail, C. (2002). Peer education, gender and the development of critical consciousness: Participatory HIV prevention by South African youth. Social Science \& Medicine, 55(2), 331-345. https://doi.org/10.1016/S0277-9536(01)00289-1

CEFM and Sexuality Programs Working Group. (2019, June 1). Tackling the Taboo: Sexuality and Gender Transformative Programmes to End Child, Early and Forced Marriage and Unions. Girls Not Brides. https://www.girlsnotbrides.org/resource-centre/tackling-the-taboo-sexualityand-gender-transformative-programmes-to-end-child-early-and-forced-marriage-and-unions/

Design-Based Research Collective. (2003). Design-based research: An emerging paradigm for educational inquiry. Educational Researcher, 32(1), 5-8. https://doi.org/10.310 2/0013189X032001005

English, L. M., \& Irving, C. J. (2015). Critical feminist pedagogy. In L. M. English \& C. J. Irving (Eds.), Feminism in community: Adult education for transformation (pp. 103-113). Sense Publishers.

Festinger, L. (1962). A theory of cognitive dissonance. Stanford University Press.

Freire, P. (2000). Pedagogy of the oppressed. Bloomsbury Publishing.

Girls Not Brides. (2020). Child marriage around the world. https://www.girlsnotbrides.org/ where-does-it-happen/

Giroux, H. A. (2004). Critical pedagogy and the postmodern/modern divide: Towards a pedagogy of democratization. Teacher Education Quarterly, 31(1), 31-47.

Gramsci, A. (1971). Selections from the Prison Notebooks (Q. Hoare and GN Smith, Trans.). Lawrence and Hishart.

Harmon-Jones, E., \& Harmon-Jones, C. (2012). Cognitive dissonance theory: An update with a focus on the action-based model. In J. Y. Shah \& W. L. Gardner (Eds.), Handbook of motivation science (pp. 71-83). The Guilford Press.

Honduran Secretary of Health, National Institute of Statistics, \& ICF International. (2013). Encuesta Nacional de Salud y Demografía 2011-2012 [National Survey of Health and Demography 2011-2012]. National Institute of Statistics. http://dhsprogram.com/publications/ publication-FR274-DHS-Final-Reports.cfm\#sthash.ohl3qWVJ.dpuf

International Center for Research on Women (ICRW). (2015). Child marriage facts and figures. http://www.icrw.org/child-marriage-facts-and-figures

McEwan, P. J., Murphy-Graham, E., Torres Irribarra, D., Aguilar, C., \& Rápalo, R. (2015). Improving middle school quality in poor countries: Evidence from the Honduran Sistema de Aprendizaje tutorial. Educational Evaluation and Policy Analysis, 37(1), 113-137. https://doi. org/10.3102/0162373714527786

Miles, M. B., Huberman, A. M., \& Saldaña, J. (2014). Qualitative data analysis: A methods sourcebook. Sage. 
Mintrop, R. (2016). Design-based school improvement: A practical guide for education leaders. Harvard Education Press.

Murphy-Graham, E. (2012). Opening minds, improving lives: Education and women's empowerment in Honduras. Vanderbilt University Press.

Murphy-Graham, E., \& Leal, G. (2015). Child marriage, agency, and schooling in rural Honduras. Comparative Education Review, 59(1), 24-49. https://doi.org/10.1086/679013

Murphy-Graham, E., Cohen, A. K., \& Pacheco-Montoya, D. (2020). School dropout, child marriage, and early pregnancy among adolescent girls in rural honduras. Comparative Education Review, 64(4), 703-724.

Pacheco Montoya, D. P. (2019). Developing a curriculum for a formal education setting to prevent child marriage in rural areas of Honduras: A design-based research study (Publication No. 27736539). Doctoral dissertation, University of California, Berkeley. ProQuest Dissertations Publishing. https://search.proquest.com/openview/7732120ccbf0ad264973ed2f3e42762f/1 ?pq-origsite $=$ gscholar $\& \mathrm{cbl}=18750 \&$ diss $=\mathrm{y}$

Plomp, T. (2010). Educational design research: An introduction. In T. Plomp \& N. Nieveen (Eds.), An introduction to educational design research (pp. 9-36). SLO Netherlands Institute for Curriculum Development.

Remez, L., Singh, S., \& Prada, E. (2009). Trends in adolescent unions and childbearing in four Central American countries. Población y salud en Mesoamérica, 7(1), 1-20.

Shrewsbury, C. (1993). What is feminist pedagogy? Women's Studies Quarterly, 21(3/4), 8-16. http://www.jstor.org/stable/40022001

Sriranganathan, G., Jaworsky, D., Larkin, J., Flicker, S., Campbell, L., Flynn, S., \& Erlich, L. (2012). Peer sexual health education: Interventions for effective programme evaluation. Health Education Journal, 71(1), 62-71. https://doi.org/10.1177/0017896910386266

Steinberg, L. (2011). Adolescence (9th ed.). McGraw-Hill.

Taylor, A., Lauro, G., Segundo, M., \& Greene, M. (2015). She goes with me in my boat' child and adolescent marriage in Brazil: Results from mixed-methods research. Instituto Promundo \& Promundo-US.

Taylor, A. Y., Murphy-Graham, E., Van Horn, J., Vaitla, B., Del Valle, Á., \& Cislaghi, B. (2019). Child marriages and unions in Latin America: Understanding the roles of agency and social norms. Journal of Adolescent Health, 64(4), S45-S51.

UNICEF. (2016). State of the world's children 2016: A chance for every child. https://www.unicef. org/publications/index_91711.html

UNICEF. (2019). Secondary education. https://data.unicef.org/topic/education/secondaryeducation/

United Nations International Children's Emergency Fund (UNICEF). (2017). Child marriage: South Asia. https://www.unicef.org/rosa/what-we-do/child-protection/child-marriage

United Nations Women (UN Women), United Nations International Children's Emergency Fund (UNICEF) \& United Nations Fund for Population Activities (UNFPA). (2018). A commitment to end child marriage and early unions. https://www.unicef.org/lac/en/reports/ commitment-end-child-marriage-and-early-unions

Walker, S. A., \& Avis, M. (1999). Common reasons why peer education fails. Journal of Adolescence, 22(4), 573-577.

World Bank. (2020). Honduras: Country overview. https://www.worldbank.org/en/country/honduras. Last accessed 23 June 2020. 
Open Access This chapter is licensed under the terms of the Creative Commons Attribution 4.0 International License (http://creativecommons.org/licenses/by/4.0/), which permits use, sharing, adaptation, distribution and reproduction in any medium or format, as long as you give appropriate credit to the original author(s) and the source, provide a link to the Creative Commons license and indicate if changes were made.

The images or other third party material in this chapter are included in the chapter's Creative Commons license, unless indicated otherwise in a credit line to the material. If material is not included in the chapter's Creative Commons license and your intended use is not permitted by statutory regulation or exceeds the permitted use, you will need to obtain permission directly from the copyright holder. 